\title{
Orta Anadolu Sulu Koşullarında Bazı Kışlık Ekmeklik Buğday Genotiplerinin Verim ve Kalite Performanslarının Belirlenmesi
}

\author{
*Mehmet ŞAHIN Aysun GÖÇMEN AKÇACIK Seydi AYDOĞAN Enes YAKIŞIR \\ Bahri Dağdaş Uluslararası Tarımsal Araştırma Enstitüsü, Konya \\ *Sorumlu yazar e-posta (Corresponding author; e-mail): mehmetsahin222@yahoo.com
}

\section{Öz}

Bu araştırmada 2009-2010, 2010-2011, 2011-2012, 2012-2013 üretim yılında, Konya lokasyonunda sulu koşullarda 18 ekmeklik buğday genotipi (08-09 SEBVD 10, Ahmetağa, Bağcı 2002, BDME 02/01S, Bezostaya 1, Demir 2000, Ekiz, Eser, Göksu 99, Gün 91, Kate A-1, Kınacı 97, Konya 2002, Pehlivan, Sönmez 2001, Sultan 95, Tosunbey, Victorya) materyal olarak kullanılmıştır. Tane verimi, bin tane ağırlığı, protein oranı, kuru gluten, Zeleny sedimantasyon, sertlik, alveograf, miksograf, ekmek hacmi ve ekmek ağırlığı özellikleri incelenmiştir. Denemede ortalama değerler; verim 522 kg/da, bin tane ağırlığı 34.9 g, protein oranı \%13.1, kuru gluten oranı \%11.1, Zeleny sedimantasyon $39.4 \mathrm{ml}$, sertlik (PSI) 47.1, alveograf enerji değeri

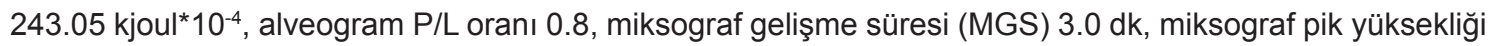
(MPY) \%65.1, miksograf toplam alan (MTAL) 350.8 (\% tq*dk), miksograf yumuşama değeri (MYUM) 19.2 \%/dk, ekmek hacmi (EHACM) 463.3 cm³ $^{3}$, ekmek ağırlığı (EAGR) $138.6 \mathrm{~g}$ olarak belirlenmiştir. incelenen genotiplerin sanayicinin ve fırıncıların talep ettikleri kalite özelliklerine sahip oldukları belirlenmiştir..

Anahtar Kelimeler: Ekmeklik buğday, verim, protein, Zeleny sedimantasyon, alveograf, miksograf

\section{Determination of Yield and Quality Performance of Winter Wheat Genotypes in Rainfed Conditions of Central Anatolian}

\begin{abstract}
In this study, 18 bread wheat genotypes (08-09 SEBVD-10, Ahmetağa, Bağcı 2002, BDMA 02/01S, Bezostaya 1, Demir 2000, Ekiz, Eser, Göksu 99, Gün 91, Kate A-1, Kınacı 97, Konya 2002, Pehlivan Sönmez 2001, Sultan 95, Tosunbey, Victorya) was used as the material in 2009-2010, 2010-2011, 2011-2012, 20122013 growing season under irrigated conditions in Konya location. Grain yield, thousand grain weight, protein content, dry gluten, Zeleny sedimentation, hardness, alveograph, mixograph, bread volume and bread weight were investigated. Average values in the experiment; yield $522 \mathrm{~kg} / \mathrm{ha}$, thousand grain weight $34.9 \mathrm{~g}$, protein content $13.1 \%$, dry gluten rate $11.1 \%$, Zeleny sedimentation $39.4 \mathrm{ml}$, hardness (PSI) 47.1 , alveograph energy value $243.05 \mathrm{kjoul}^{*} 10^{-4}$, alveograph $\mathrm{P} / \mathrm{L}$ ratio 0.8 , mixograph development time (MGS) 3.0 min., mixograph peak height (MPY) 65.1\%, mixsograph total area (MTAL) 350.8 (tq \% * min), mixograph softening value (MYUM) $19.2 \%$ / min., bread volume (EHACM) $463.3 \mathrm{~cm}^{3}$, bread weight (EAGR) $138.6 \mathrm{~g}$. was determined. studied genotypes were determined to have the quality characteristics demanded by industrialists and bakers.
\end{abstract}

Keywords: Bread wheat, grain yield, protein, Zeleny sedimantation, alveograph, mixograph

\section{Giriş}

D uğday Türkiye ekonomisi için büyük önem taşımaktadır. Ülkemizde gerek ekmek sanayisi gerekse bulgur, makarna ve bisküvi sanayisi açısından temel hammadde oluşu nedeniyle vazgeçilmez tarım ürünlerimizdendir. Yıllık yaklaşık 19 milyon ton üretim kapasitemize rağmen bazı yıllarda iç talep karşılanamamakta ve dış alım yapılmaktadır. Bazı yıllarda iklim koşullarının kötü geçmesi (yağış, sıcaklık v.b) veya süne zararına mahsur kalmış buğdayın kalite değerlerinin düşmesi nedeniyle dış alım yapılarak açık kapatılmaktadır. Buğdayda kalite deyimi, buğdayı kullanan sanayiciye göre farklı anlamlara gelmektedir. Kalite, genellikle istenilen özelliklere uygun olmayı işaret etmektedir. Buğday kalitesinin tarifi, unun üretim ünitesindeki mevcut şartlarda her zaman rekabet edilebilir fiyatta cazip ürün meydana getirebilme kabiliyetidir. Genellikle kuvvetli un 
deyimi ile kaliteli un deyimi eş anlamda kullanılmaktadır. Unun bir amaç için kullanmaya elverişli olmasını veya olmamasını, kuvvetli veya zayıf oluşu tayin etmektedir. Unun kuvvetli oluşu genellikle proteinle ilişkilidir ve proteinin miktar ve kalitesini birlikte intiva etmektedir (Şahin ve ark. 2009).

Miksograf sabitleştirilmiş ve dönen pimlerin kombinasyonu kullanılarak un ve suyun karıştırılma esasına göre çalışan, hamurun yoğrulmaya karşı direncini ölçerek buğday ve un kalitesini tahmin eden bir laboratuvar cihazıdır (Khatkar et al. 1996). Miksograf kürvesinin analiz edilmesiyle buğday ununun üç önemli özelliği tahmin edilebilmektedir. Bunlar optimum yoğrulma zamanı, yoğrulmaya karşı direnç ve protein kalitesidir. Tepe noktası miksograftan elde edilen en yüksek noktadır. Bu noktada hamur optimum gelişmeye sahiptir. Tepe noktasına ulaşmak için gerekli olan zaman, gluten proteinlerinin sağlamlığı konusunda bilgi vermektedir. Tepe noktasından sonra miksograf kürvesi aşağı doğru iner, kürvenin genişliği ve aşağı doğru inme açısı fazla yoğrulmaya karşı hamurun toleransını gösterir (Bağcı ve Şahin, 1999).

Buğday unu hamur yapıldığı zaman unlu mamullerin üretimi için gerekli olan gaz tutma yeteneğine sahip viskoelastik bir form oluşturmaktadır. Hamur oluşumundan sorumlu protein gluten olup, fermantasyon ve karıştırma işlerinde hamurun reolojik özelliklerine etkisi vardır. Elastikiyet, viskozite, uzayabilme kabiliyeti gibi reolojik özelliklerin tahmini ve ölçülmesi ekmek sanayicisi açısından önemlidir (Hruskova and Smejda 2003). Başlangıçta yumuşak buğday ununun ekmeklik kalitesini değerlendirmek için bir deneysel fizik testi olarak Fransa'da geliştirilen alveograf tekniği, şu anda birçok ülkede yaygın olarak kullanılmaktadır (Khattak et al. 1974)

Bu çalışmada 18 adet buğday genotipi 4 yıl süresince denenerek verim, miksograf, alveograf ve bazı kalite özellikleri yönüyle değerlendirilmiştir.

\section{Materyal ve Yöntem}

Bu araştırmada 2009-2010, 2010-2011, 2011-2012, 2012-2013 üretim yılında, Konya merkez lokasyonunda sulu koşullarda 18 farklı ekmeklik buğday genotipi materyal olarak kullanılmıştır (Çizelge 1). Sulu koşullarda ekimle birlikte her parsele $4 \mathrm{~kg} / \mathrm{da} \mathrm{N}$ ve $9 \mathrm{~kg} / \mathrm{da} \mathrm{P}_{2} \mathrm{O}_{5}$ verilmiştir. Üst gübre olarak $8 \mathrm{~kg} / \mathrm{da} \mathrm{N}$ verilmiştir.
Verim, bin tane ağırlığı, protein oranı, kuru gluten, Zeleny sedimantasyon, sertlik değeri belirlenmiştir. Bin tane ağırlığı, protein oranı, kuru gluten, Zeleny sedimantasyon, sertlik değeri 2'şer tekerrürlü olarak analiz edilmiş olup, reolojik testlerden alveograf, miksograf ve ekmek yapım denemeleri tekerrürler birleştirilerek tek tekerrür üzerinden değerlendirilmiştir

Araştırmada genotiplerin bin tane ağırlığı Williams et al. (1988)' e göre; protein miktarı, AACC 39-10'a göre; sertlik (particle size index) ve kuru gluten ise Near infrared reflektans spektroskopi (NIR) cihazı ile analiz edilmiştir (Anon. 1990). Zeleny sedimantasyon ICC-116 (Anon. 1981)'e göre analiz edilmiştir. Buğday örnekleri AACC metod 26-95'e göre \%14.5 rutubet esasına göre tavlanarak Brabender Junior marka değirmende 6xx elek kullanılarak öğütülmüş olup elde edilen unlarda reolojik analizler yapılmıştır.

Alveograf analizi; AACC 54-30A metoduna göre belirlenmiştir (Anon. 1990). Alveograf, hamurun uzamaya karşı gösterdiği direnci ölçmek için geliştirilmiş bir alettir. Deneyin prensibi; sabit şartlar altında un, tuz ve su ile hazırlanan hamurdan belli ağırlıkta kesilen ve belli şekil verilen hamur parçalarının bir süre bekletilip hava ile şişirilmesi ve böylece hamurun uzamaya (şişmeye) karşı gösterdiği direncin ölçülmesidir. Hamurun uzamaya karşı gösterdiği direncin bir kürve halinde (alveogram) kaydedilmesinden sonra elde edilen kürvenin yüksekliği, taban uzunluğu, alanı ile şişen hamurun patlama anındaki hacmi bize unun ekmek değeri hakkında fikir verir (Elgün ve ark. 2001).

Miksograf analizi AACC 54-40 (Anonim 1990) göre National Mfg.Co. Lincoln. NE miksograf cihazı kullanılarak yapılmıştır. Mixsmart yazılımı ile sonuçlar bilgisayar ortamından alınmıştır. Miksograf analizi ile miksograf gelişme süresi, miksograf stabilite, miksograf pik yüksekliği, miksograf yumuşama derecesi, miksograf pik alanı, miksogram kürvesi toplam alan değerleri hesaplanmıştır.

Ekmek pişirme denemelerinde, katkısız direkt hamur işlemini esas alan (AACC-10/10) ekmek pişirme metodu modifiye edilerek kullanılmıştır (Elgün ve ark. 2001). 100 gram una \%2 maya, \%1.5 rafine tuz ve farinografta kaldırdığı suyun $\% 2$ fazlası verilerek hamur olgunlaşıncaya kadar yoğurulmuştur. Her bir hamur fermantasyon kaplarına konularak \%70 nispi rutubetteki 
Çizelge 1. Deneme materyali listesi

Table 1. Material List

\begin{tabular}{llclll}
\hline No & Genotip adı & No & Genotip adı & No & Genotip adı \\
\hline 1 & 08-09 SEBVD 10 & 7 & Ekiz & 13 & Konya 2002 \\
2 & Ahmetağa & 8 & Eser & 14 & Pehlivan \\
3 & Bağcı 2002 & 9 & Göksu 99 & 15 & Sönmez 2001 \\
4 & BDME 02/01S & 10 & Gün 91 & 16 & Sultan 95 \\
5 & Bezostaya 1 & 11 & Kate A-1 & 17 & Tosunbey \\
6 & Demir 2000 & 12 & Kınacı 97 & 18 & Victorya \\
\hline
\end{tabular}

fermantasyon dolabında $30^{\circ} \mathrm{C}$ 'de 30 dakika dinlendirilip havalandırılmıştır. İkinci kez 30 dakikalık fermantasyon sonunda şekil verilip ekmek pişirme kaplarında 55 dakikalık fermantasyondan sonra $230{ }^{\circ} \mathrm{C}$ 'deki taş tabanlı pişirme fırınında 25 dakika pişirilmiştir. Ekmek hacmi, içinde sorgum tohumu bulunan ekmek hacmi ölçme cihazı ile yer değiştirme metoduna göre ölçülmüş; ekmek ağırlıkları ise terazide tartılarak kaydedilmiştir. İstatistiki analizler Jmp11 (2014) istatistik programı ile hesaplanmıştır

\section{Bulgular ve Tartışma}

Verilerin yıllara göre birleştirilmiş varyans analiz tablosu Çizelge 2'de yer almaktadır. Verim yönüyle genotipler ve yıllar arasındaki farklılıklar ve genotip yıl interaksiyonu önemli olmuştur. Yıllar ortalamasına göre en düşük verim değeri 404.0 kg /da ile Göksu 99 çeşidinde, en yüksek verim değeri 679.8 kg/da ile Konya 2002 çeşidinde belirlenmiştir. Genotiplerin ortalama verimleri 522 kg/da olarak bulunmuştur. Kınacı97, Ahmetağa, BDME02/01S, Kate A-1, Ekiz, Tosunbey, Demir 2000, Victorya genotiplerinin ortalamanın üzerinde yer aldıkları belirlenmiştir.

Bin tane ağırlığı yönüyle genotipler ve yıllar arasındaki farklılıklar ve genotip yıl interaksiyonu önemli olmuştur (Çizelge 2). Yıllar ortalamasına göre bin tane ağırlığı ortalama değeri $34.9 \mathrm{~g}$ olurken en düşük bin tane ağırlığına Göksu 99 $(28.4 \mathrm{~g})$, en yüksek bin tane ağırlığına Pehlivan (42.8 g) çeşidi sahip olmuştur. Konya 2002, Bezostaya 1, Demir 2000, 08-09-SEBVD 10,
Sönmez 2001, Victorya, Ekiz ve Tosunbey çeşitlerinin ortalama üzerinde bin tane ağırlığına sahip oldukları belirlenmiştir.

Protein oranı yönüyle genotipler ve yıllar arasındaki farklılıklar ve genotip yıl interaksiyonu önemli olmuştur (Çizelge 2). Yıllar ortalamasına göre protein oranı ortalama değeri \%13.1 olurken; en düşük protein oranına BDME 02/01S hattı (\%12.1), en yüksek protein oranına ise Demir 2000 ve Gün 91 çeşitleri (\%13.7) sahip olmuştur. Bezostaya 1, Sultan 95, Bağcı 2002, 08-09 SEBVD 10, Eser, Tosunbey, Sönmez 2001 çeşitlerinin ortalama üzerinde bin tane ağırlığına sahip oldukları belirlenmiştir. Genotiplerin kuru gluten içerikleri yönüyle yıllar ortalaması \%11.1 olmuş, genotiplerin kuru gluten içeriklerinin protein oranlarına paralel benzer bir sıralamada olduğu belirlenmiştir (Çizelge 3).

Zeleny sedimantasyon açısından genotiplerin yıllar ortalamasının 39.4 ml olduğu belirlenmiş; Kate A-1 $29.6 \mathrm{ml}$ ile en düşük değere sahip olurken, Gün 91 çeşidi $48.6 \mathrm{ml}$ ile en yüksek değere sahip olmuştur. Victorya, Bağcı, Tosunbey, Bezostaya 1, Eser ve Ahmetağa çeşitlerinin ise ortalama üzerinde değere sahip oldukları belirlenmiştir.

Sertlik değerleri yıllar ortalaması PSI index cinsinden ortalama 47.1 olurken, en sert çeşit Kate A-1 (36.6), en yumuşak genotip ise Göksu99 (69.9) çeşidi olmuştur. Ekmeklik buğdayların sert olması arzu edilen bir durumdur.

Çizelge 2. Varyans analiz değerleri

Table 2. Variance Analysis

\begin{tabular}{llllllll}
\hline Kaynak & SD & Verim & BNT & PRT & KGLT & ZLN & SRT \\
\hline Genotip & 17 & $69.3^{* *}$ & $179.25^{* *}$ & $9.26^{* *}$ & $12.77^{* *}$ & $67.91^{* *}$ & $41.3^{* *}$ \\
YIl & 3 & $71.29^{* *}$ & $109.75^{\star *}$ & $110.49^{* *}$ & $14.52^{* *}$ & $16.55^{* *}$ & $7.04^{* *}$ \\
Tekerrür & 1 & 3.948 & 1.1085 & 5.93 & 6.34 & 0.1412 & 2.9065 \\
Gen x YII & 51 & $19.148^{* *}$ & $11.90^{* *}$ & $3.087^{*}$ & $4.63^{* *}$ & $33.77^{* *}$ & $2.59^{* *}$ \\
Genel & 143 & $32.95^{* *}$ & $53.34^{* *}$ & $9.10^{* *}$ & $7.02^{* *}$ & $40.65^{* *}$ & $11.94^{* *}$ \\
\hline & VK & 15.3 & 2.46 & 2.57 & 3.51 & 3.93 & 6.57 \\
& LSD & 27.99 & 0.86 & 0.46 & 0.37 & 1.54 & 4.53 \\
\hline
\end{tabular}

${ }^{*} \mathrm{P}<0.0,{ }^{* *}: \mathrm{p}<0.01$. SD: Serbestlik derecesi, Verim:Tane verimi (kg/da.), BNT:Bin tane ağılığı (g), PRT:Protein oranı(\%), KGLT:Kuru gluten oranı (\%), ZLN: Zeleny sedimantasyon (ml), SRT:Sertlik (PSI).

${ }^{*} P<0.0,{ }^{* *} P<0.01$. SD: Degree of Freedom, Verim: Grain yield (kg/da), BNT: thousand grain weight (g) PRT: protein content (\%), KLGT: dry gluten rate (\%), ZLN: Zeleny sedimentation (ml), SRT: hardness (PSI) 
Genotiplerin alveograf enerji değeri yıllar ortalaması $243.48 \mathrm{kj} \mathrm{x} 10^{-4}$ olup, Tosunbey çeşidinin (331.45 kj x 10-4) ilk sırada yer aldığı Kate A-1 çeşidinin ise $\left(157.72\right.$ kjoul* $\left.^{*} 0^{-4}\right)$ son sırada yer aldığı belirlenmiştir. Ayrıca Ukrayna, Ahmetağa, 08-09 SEBVD 10, BDME02/01S, Bezostaya 1, Sönmez 2001, Konya 2002 çeşitlerinin ortalama üzerinde olduğu belirlenmiștir. Alveogram P/L oranı önemli olup bu oranın 1 civarında olması ekmek özellikleri açısından istenen bir durumdur. Bu çalışmada ortalama $\mathrm{P} / \mathrm{L}$ oranı 0.76 olmuş, en yüksek $\mathrm{P} / \mathrm{L}$ oranına 08-09 SEBVD 10 nolu genotip 1.11 ile sahip olmuş, Eser çeşidi 0.48 ile son sırada yer

Çizelge 3. Genotiplerin verim ve bazı kalite özellikleri

Table 3. Yield and some quality parameters of genotypes

\begin{tabular}{lcccccccc}
\hline \multicolumn{1}{c}{ Genotip } & Verim & BNT & PRT & KGLT & ZLN & SRT & ENERJi & P/L \\
\hline 08-09 SEBVD 10 & 492.9 & 37.7 & 13.2 & 11.3 & 36.9 & 40.0 & 296.9 & 1.1 \\
Ahmetağa & 624.3 & 30.8 & 12.9 & 10.9 & 41.4 & 40.3 & 308.0 & 0.6 \\
BağCI 2002 & 416.3 & 33.8 & 13.6 & 11.3 & 44.9 & 50.0 & 233.4 & 0.7 \\
BDME 02/01S & 595.9 & 33.1 & 12.1 & 10.1 & 38.1 & 37.4 & 293.1 & 0.9 \\
Bezostaya 1 & 440.0 & 38.8 & 13.6 & 11.6 & 42.0 & 43.2 & 281.6 & 0.9 \\
Demir 2000 & 530.1 & 38.4 & 13.7 & 11.7 & 38.1 & 47.6 & 216.9 & 1.0 \\
Ekiz & 537.0 & 35.2 & 13.3 & 11.3 & 36.0 & 43.4 & 180.0 & 0.8 \\
Eser & 500.2 & 29.1 & 13.2 & 11.3 & 42.0 & 67.3 & 186.9 & 0.5 \\
Göksu 99 & 404.0 & 28.4 & 13.5 & 11.4 & 36.3 & 69.9 & 192.3 & 0.6 \\
Gün 91 & 439.1 & 34.2 & 13.7 & 11.7 & 48.6 & 44.6 & 242.6 & 0.8 \\
KateA-1 & 593.1 & 33.5 & 12.6 & 10.6 & 29.6 & 36.6 & 157.7 & 0.5 \\
Kınacı-97 & 655.5 & 32.1 & 12.2 & 10.2 & 38.1 & 42.0 & 240.6 & 0.7 \\
Konya 2002 & 679.8 & 42.5 & 12.9 & 10.9 & 34.5 & 48.6 & 248.4 & 1.0 \\
Pehlivan & 514.1 & 42.8 & 12.8 & 10.8 & 38.6 & 42.1 & 198.2 & 1.0 \\
Sönmez 2001 & 488.3 & 37.3 & 13.1 & 11.1 & 36.8 & 38.3 & 250.9 & 0.6 \\
Sultan 95 & 418.6 & 30.6 & 13.6 & 11.6 & 38.9 & 67.3 & 207.1 & 0.5 \\
Tosunbey & 536.6 & 34.9 & 13.1 & 11.4 & 44.1 & 42.5 & 331.5 & 0.8 \\
Victorya & 529.9 & 35.5 & 12.4 & 10.4 & 45.1 & 46.7 & 316.8 & 0.7 \\
\hline Ortalama & 522.0 & 34.9 & 13.1 & 11.1 & 39.4 & 47.1 & 243.05 & 0.8 \\
\hline
\end{tabular}

Verim:Tane verimi(kg/da.), BNT:Bin tane ağırlığı(g), PRT:Protein oranı(\%), KGLT:Kuru gluten oranı(\%), ZLN: Zeleny sedimantasyon (ml), SRT:Sertlik(PSI), ENERJi:Alveograf enerji (kjoul $\left.{ }^{*} 10^{-4}\right)$, P/L:Alveogram P/L oranı

Verim: Grain yield (kg/da), BNT: thousand grain weight (g) PRT: protein content (\%), KLGT: dry gluten rate (\%), ZLN: Zeleny sedimentation (ml), SRT: hardness (PSI), ENERGY: alveograph energy value (kjoul * $\left.10^{-4}\right), P / L$ : alveograph $P / L$ ratio

Çizelge 4. Miksograf parametreleri, ekmek hacmi ve ekmek ağırlığı ortalama değerleri Table 4. Mixograph parameters, loaf volume and loaf weight averages of genotypes

\begin{tabular}{|c|c|c|c|c|c|c|}
\hline Genotip & MGS & MPY & MTAL & MYUM & EHACM & EAGR \\
\hline 08-09 SEBVD 10 & 3.3 & 68.3 & 372.4 & 19.7 & 540.0 & 143.1 \\
\hline Ahmetağa & 3.8 & 63.3 & 340.0 & 14.1 & 520.0 & 138.9 \\
\hline Bağcı 2002 & 2.8 & 69.9 & 369.4 & 18.1 & 535.0 & 135.4 \\
\hline BDME 02/01S & 4.3 & 57.8 & 327.8 & 11.5 & 437.5 & 151.1 \\
\hline Bezostaya 1 & 2.7 & 63.7 & 346.0 & 17.4 & 465.0 & 137.4 \\
\hline Demir 2000 & 1.8 & 74.8 & 379.0 & 34.0 & 485.0 & 136.7 \\
\hline Ekiz & 2.3 & 62.1 & 327.6 & 23.4 & 452.5 & 134.3 \\
\hline Eser & 3.3 & 57.9 & 319.4 & 14.2 & 425.0 & 137.6 \\
\hline Göksu 99 & 3.2 & 62.4 & 351.9 & 14.6 & 392.5 & 137.0 \\
\hline Gün 91 & 2.9 & 73.6 & 389.9 & 20.8 & 462.5 & 140.4 \\
\hline KateA-1 & 2.0 & 63.7 & 329.2 & 30.0 & 480.0 & 136.1 \\
\hline Kınacı 97 & 3.8 & 63.4 & 350.6 & 13.4 & 450.0 & 134.2 \\
\hline Konya 2002 & 2.5 & 69.4 & 373.1 & 23.3 & 482.5 & 141.9 \\
\hline Pehlivan & 2.0 & 63.4 & 332.1 & 23.5 & 432.5 & 137.8 \\
\hline Sönmez 2001 & 1.9 & 70.5 & 363.4 & 28.3 & 485.0 & 134.0 \\
\hline Sultan 95 & 3.0 & 58.8 & 327.8 & 13.4 & 385.0 & 138.7 \\
\hline Tosunbey & 4.3 & 65.4 & 353.4 & 12.9 & 437.5 & 141.2 \\
\hline Victorya & 3.6 & 65.6 & 360.6 & 13.7 & 472.5 & 139.2 \\
\hline Ortalama & 3.0 & 65.1 & 350.8 & 19.2 & 463.3 & 138.6 \\
\hline
\end{tabular}

MGS: Miksograf gelişme süresi (dak.), MPY:Pik yüksekliği (\%), MTAL: Toplam alan (\%tq*dk), MYUM: Sağ pik eğimi (\%/dk.), EHACM: Ekmek hacmi $\left(\mathrm{cm}^{3}\right)$, EAGR: Ekmek ağırlığı $(\mathrm{g})$

MGS: Mixograph development time (min), MPY: Mixograph peak height (\%), MTAL: Mixsograph total area (tq \% * min), MYUM: Mixograph softening value (\% / min.), EHACM: $\left(\mathrm{cm}^{3}\right)$, EAGR: bread weight $(\mathrm{g})$ 
almıştır. Ekmek özellikleri açısından Demir 2000, Pehlivan, Konya 2002, Bezostaya 1 çeşitlerinin $\mathrm{P} / \mathrm{L}$ oranları 0.90 üzerinde olmuş olup un sanayicisinin istediği özelliklere yakın değerlerde olduğu tespit edilmiştir.

Şahin ve ark. (2009), Orta Anadolu şartlarında geliştirilmiş kuru şartlar için 18 , sulu şartlar için 16 kışlık ekmeklik buğday genotipi ile kuru (5) ve sulu (8) farklı çevre şartlarında yaptıkları bir çalışma sonucunda kurudaki çeşitlerin alveograf enerji ortalama değerinin 211 $\mathrm{kj} \times 10^{-4}$, sulu şartlardakilerin ise $212.3 \mathrm{kj} \times 10^{-4}$ olduğunu, kuru şartlardaki genotiplerin ortalama $\mathrm{P} / \mathrm{L}$ oranının 0.51 , sulu şartlarda ortalama $\mathrm{P} / \mathrm{L}$ oranının 0.67 olduğunu belirlemişlerdir. Ekmeklik buğday ıslah çalışmalarında özellikle sertlik değeri yüksek genotipler üzerinde çalışıması ile alveogram (W) değerlerinin daha iyi olacağını belirtmişlerdir.

Miksograf gelişme süresi deneme ortalaması $3.00 \mathrm{dk}$ olarak belirlenmiştir. En yüksek değere $4.29 \mathrm{dk}$ ile BDME 02/01S, en düşük değere ise 1.79 dk ile Demir 2000 çeşidi sahip olmuştur. MGS yüksek olması unun gluten kuvvetinin yoğurmaya karşı toleransını göstermektedir ve yüksek olması sanayici açısından istenen bir durumdur. Miksograf pik yüksekliği ortalama değeri \%65.1 olmuş, en yüksek değere $\% 74.84$ ile Demir 2000 çeşidi sahip olurken, en düşük değere \%57.80 ile BDME02/01S ve Eser çeşidinin sahip oldukları belirlenmiştir. Pik yüksekliğinin yüksek değere sahip olması hamurun yoğurmaya karşı direncini göstermektedir ki ekmeklik değeri açısından yüksek olması istenen bir durumdur. Miksogram toplam alan (MTAL) deneme ortalaması 350.8 \%tq $x$ dk olmuş, en yüksek değere Gün 91 çeşidi (389.9 \%tq $x \mathrm{dk}$ ) sahip olurken, en düşük değere Eser (319.3 \%tq $x$ dk) çeşidinin sahip olduğu belirlenmiştir. Miksogram sağ pik eğimi yumuşama derecesi olarak değerlendirilmiş olup deneme ortalaması $19.24 \% / d k$ olmuş, BDME 02/01S hattının (11.47\%/dk) en düşük değere sahip olduğu belirlenmiştir. Miksograf yumuşama değerinin düşük olması hamurun yoğrulmaya karşı toleransının yüksek olduğunu göstermesi açısından istenen bir durumdur.

Ekmek hacmi deneme ortalaması (EHACM) $463.3 \mathrm{~cm}^{3}$ olmuş, en yüksek ekmek hacmine 540 $\mathrm{cm}^{3}$ ile 08-09 SEBVD 10 genotipi sahip olurken, en düşük ekmek hacmine ise $385 \mathrm{~cm}^{3}$ ile Sultan çeşidinin sahip olduğu belirlenmiştir. Ekmek ağırlığı deneme ortalamasının $138.6 \mathrm{~g}$ olduğu belirlenmiştir.

\section{Sonuç}

Araştırmanın yürütüldüğü yıllarda verim ve kalite özelliklerinin yıllar arasındaki ve genotipler arasındaki farklılıklarının önemli olduğu belirlenmiştir. Protein oranı, Zeleny sedimantasyon, alveograf enerji değeri ve ekmek hacmi yönüyle değerlendirilen genotiplerin kalite özelliklerinin sanayicinin ve fırıncıların talep ettikleri özellikleri karşılayacak potansiyele sahip oldukları belirlenmiştir. Yumuşak özelliğe sahip Eser, Göksu 99, Sultan 95 çeşitlerinin ekmeklik özellikleri açısından diğer deneme materyallerine göre zayıf oldukları belirlenmiştir. Bu genotiplerin yumuşak buğday ürünlerinde kullanımının daha uygun olacağı muhtemeldir.

\section{Kaynaklar}

Anonymous, 1981. ICC Standarts. International Association for Cereal Chemistry. Vienna

Anonymous, 1990. AACC Approved Methods of the American Association of Cereal Chemist, USA

Bağcı S.A. ve Şahin M., 1999. Buğday Kalite Islahında Bilgisayarlı Mixograf Aletinin Kalite Ölçümünde Kullanılması. Orta Anadolu'da Hububat Tarımının Sorunları ve Çözüm Yolları, 8-11 Haziran, s:519-523 Konya

Elgün A., Türker S. ve Bilgiçli N., 2001. Tahıl Ürünlerinde Analitik Kalite Kontrolü. Konya Ticaret Borsası. Yayın No: 2, Konya

Hruskova M. ve Smejda P., 2003. Wheat flour dough alveograph characteristics predicted by NIRSystems 6500. Czech J. Food Sci., 21: 28-33

Jmp11, 2014.JSL Syntax Reference. SAS Institute. ISBN:978-1-62959-560-3

Khatkar B.S., Bell A.E. and Schofield, J.D., 1996. A comparative study of the interrelationship between mixograph parameters and breadmaking qualities of wheat flours and glutens. J. Sci. Food Agric., 72:71-85

Khattak S., D’Appolonia R.H. and Banasık O.J., 1974. Use of the alveograph for quality evaluation of HRS wheat. Cereal Chem., 51: 355-351

Şahin M., Aydoğan S., Göçmen Akçacık A. ve Taner S., 2009. Orta Anadolu için Geliştirilmiş Bazı Ekmeklik Buğday Genotiplerinin Alveograf Analizi Yönünden Değerlendirilmesi. Bahri Dağdaş Uluslararası Tarımsal Araştırma Enstitüsü. Bitkisel Araştırma Dergisi, 2: 1-9

Williams P., El-Haramein J.F., Nakkoul H. abd Rihawi S, 1988. Crop Quality Evaluation Methods and Guidelines. Sodium Dodecyl Sulphate (SDS) Sedimentation. P: 13-16 International Center For Agricultural Research in The Dry Areas (ICARDA), Syri 